\title{
ELECTRONMICROSCOPY OF THE SURFACE OF PASTEURELLA HAEMOLYTICA
}

\author{
N. J. L. Gilmour, J. D. Menzies, W. Donachie and J. Fraser \\ Moredun Research Institute, 408 Gilmerton Road, Edinburgh EH17 7JH
}

\begin{abstract}
Summary. The surfaces of Pasteurella haemolytica, biotype A, serotypes 1, 2, 6, 7 and 9 and of $P$. haemolytica, biotype T serotypes 3, 4, 10 and 15 were examined by transmission electronmicroscopy with ruthenium red staining and polycationic ferritin labelling, by scanning electronmicroscopy, and by light microscopy. Electronmicroscopy showed that the surface of strains of $P$. haemolytica biotype A was covered by irregular protrusions which were probably capsular material. The surface and general morphology of $P$. haemolytica biotype $\mathrm{T}$ were distinct from those of biotype A.
\end{abstract}

\section{INTRODUCTION}

Isolates of Pasteurella haemolytica are serotyped by an indirect haemagglutination (IHA) test in which specific, capsular antigens are thought to participate (Biberstein, Gills and Knight, 1960). Although it has been stated that the capsule of $P$. haemolytica is difficult to demonstrate by simple microscopical techniques (Smith, 1974), Corstvet et al. (1982) have recently demonstrated by fluorescence microscopy the presence of an age-dependent capsule on $P$. haemolytica biotype A, serotype 1 (A1). As part of our work on the physical and chemical characterisation of antigens from $P$. haemolytica, we examined several strains by electronmicroscopy to study the morphology of the cells and the effect of an extraction method on them. Preliminary experiments with two strains, types $\mathrm{Al}$ and T10 (biotype T, serotype 10) indicated potentially important differences between the $\mathrm{A}$ and $\mathrm{T}$ biotypes and we proceeded to examine further representatives of each biotype to investigate the suggestion of Smith and Thal (1965) that the A and T biotypes of Smith (1961) might belong to separate species.

\section{MATERIALS AND METHODS}

Strains of P. haemolytica. These were isolated from fatal cases of pasteurellosis in sheep and used in these studies after fewer than six subcultures on laboratory media. They were stored lyophilised or at $-70^{\circ} \mathrm{C}$. The two strains used in a preliminary experiment were $P$. haemolytica, biotype A, serotype 1 (A1), strain FA1, and biotype T, serotype 10 (T10), strain FT10. Strain FT10 and eight other strains were used in the main experiment (table I).

Growth of bacteria. Bacteria were grown in No. 2 Broth (Oxoid) for $18 \mathrm{~h}$ at $37^{\circ} \mathrm{C}$ for ruthenium red staining, or on Blood Agar Base (CM55, Oxoid) supplemented with galactose $1 \%$ 
TABLE I

TEM of serotypes of Pasteurella haemolytica stained with ruthenium red

\begin{tabular}{lc|lll}
\hline & & \multicolumn{3}{|c}{$\begin{array}{c}\text { Morphological features of material } \\
\text { stained with ruthenium red }\end{array}$} \\
\cline { 3 - 5 } Strain & Serotype & Aggregations & $\begin{array}{c}\text { Closely associated } \\
\text { layer }\end{array}$ & Projections \\
\hline FA1 & A1 & Large & Present & None seen \\
V965B & A1 & None seen & Present & None seen \\
T884 & A2 & None seen & None seen & None seen \\
FA6 & A6 & Large & None seen & None seen \\
FA7 & A7 & None seen & Present & None seen \\
FA9 & A9 & None seen & Present & Finger-like \\
FT3 & T3 & Large & Present & None seen \\
T164A & T4 & None seen & None seen & None seen \\
FT10 & T10 & Small & Present & Thin strands \\
S886B & T15 & Large & Present & Thin strands \\
& & & &
\end{tabular}

(galactose agar) (Wessman, 1966) for $18 \mathrm{~h}$ for ruthenium red staining and ferritin labelling and for 6 or $18 \mathrm{~h}$ for scanning electronmicroscopy. In the main experiment all nine strains were grown on galactose agar and were inoculated, incubated and harvested as one batch.

Extraction with sodium salicylate. The extraction method described by Gilmour et al. (1983) was used. $P$. haemolytica strain FAl was grown in $1.5 \mathrm{~L}$ of broth, harvested by centrifugation and extracted with $150 \mathrm{ml}$ of $1 \mathrm{M}$ sodium salicylate. The mixture was shaken at $37^{\circ} \mathrm{C}$ for $3 \mathrm{~h}$ and the cells harvested by centrifugation at $28000 \mathrm{~g}$ for $40 \mathrm{~min}$ at $4{ }^{\circ} \mathrm{C}$. The pellets of cells were washed and then treated with ruthenium red or polycationic ferritin.

Ruthenium red staining. Bacterial cells were treated with ruthenium red as described by Howard and Gourlay (1974) except that the concentrations of glutaraldehyde and osmium tetroxide were decreased to $2.5 \%$ and $1 \%$ respectively. Unstained bacteria were examined as controls.

Polycationic ferritin labelling. The bacteria were labelled with polycationic ferritin (Miles Laboratories, Stoke Poges, Slough) according to the method of Weiss, Schiefer and Krauss (1979). Bacteria grown on galactose agar were centrifuged, suspended in RK buffer $(20 \% \mathrm{v} / \mathrm{v})$ (Ryter et al., 1958) and mixed with the ferritin $(0.825 \mathrm{mg} / \mathrm{ml})$ for $30 \mathrm{~min}$ at room temperature; the reaction was stopped by the addition of a ten-fold volume of RK buffer. The cells were collected by centrifugation at $6000 \mathrm{~g}$ for $5 \mathrm{~min}$, washed five times in RK buffer and prepared for electronmicroscopy by the method of Wagner et al. (1980) but omitting the embedding step in Noble agar.

Bacteria treated with ruthenium red and polycationic ferritin were dehydrated in graded ethanols and embedded in Araldite. Sections were stained with uranyl acetate and lead citrate and examined by transmission electronmicroscopy (TEM) in a Siemens' 1 A electronmicroscope.

Scanning electronmicroscopy (SEM). Colonies of bacteria grown on galactose agar were fixed by gently flooding the plate with glutaraldehyde $2.5 \%$ in $0 \cdot 1 \mathrm{M}$ phosphate buffer, $p \mathrm{H} 7 \cdot 3$, for $1 \mathrm{~h}$ at room temperature. Colonies on pieces of agar $8 \mathrm{~mm}$ in diameter were rinsed with $0 \cdot 1 \mathrm{M}$ phosphate buffer containing dextrose $2 \%$ and then post-fixed in osmium tetroxide $1 \%$ in $0 \cdot 1 \mathrm{M}$

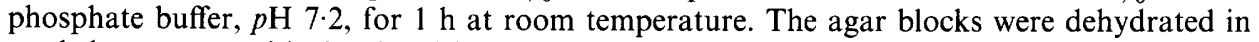
graded acetones, critical point dried and coated with $15 \mathrm{~nm}$ of gold-palladium in a Polaron sputter coater. Specimens were examined in a Jeol T300 scanning electronmicroscope at $24 \mathrm{kV}$.

Capsule staining. Cultures of $P$. haemolytica grown for $18 \mathrm{~h}$ on galactose agar were examined for capsules by Maneval's method (1941). Equal volumes of $1 \%$ aqueous Congo red and a suspension of organisms in phosphate buffered saline (PBS) were mixed, spread in a thin film on a glass microscope slide and allowed to dry. Without fixation the films were stained with Maneval's stain for $5 \mathrm{~min}$, drained and blotted. 
TABLE II

Electron microscopy of P. haemolytica

\begin{tabular}{|c|c|c|c|c|}
\hline \multirow[b]{2}{*}{ Serotype } & \multicolumn{3}{|c|}{ Appearance in SEM } & \multirow{2}{*}{$\begin{array}{l}\text { Appearance after ferritin } \\
\text { labelling }\end{array}$} \\
\hline & Shape & Surface & Protrusions & \\
\hline $\begin{array}{l}\text { A1 } \\
\text { (strain FA1) }\end{array}$ & $\mathrm{R}$ & $S$ & many, regular & $\begin{array}{l}\text { complete and incomplete } \\
\text { layers, sometimes clear zone } \\
\text { between ferritin and cell walls }\end{array}$ \\
\hline $\begin{array}{l}\text { A1 } \\
\text { (strain V965B) }\end{array}$ & $\mathrm{R}$ & $S$ & many, regular & complete and incomplete layers \\
\hline & $\mathrm{R}$ & RH & few, irregular & $\begin{array}{l}\text { complete and incomplete layers } \\
\text { (as V965B) }\end{array}$ \\
\hline A6 & $\mathrm{R}$ & $\mathrm{S}$ & $\begin{array}{l}\text { many, regular } \\
\text { (as Al) }\end{array}$ & $\begin{array}{l}\text { complete and incomplete layers } \\
\text { (as V965B) }\end{array}$ \\
\hline $\begin{array}{l}\text { A7 } \\
\text { A9 }\end{array}$ & $\begin{array}{l}\mathrm{ND} \\
\mathrm{R}\end{array}$ & $\begin{array}{l}\mathrm{ND} \\
\mathrm{S}\end{array}$ & $\begin{array}{l}\text { not done } \\
\text { many, regular } \\
\text { (as A1) }\end{array}$ & $\begin{array}{l}\text { discrete conglomerations } \\
\text { complete and incomplete layers } \\
\text { (As V965B) and } \\
\text { finger-like projections }\end{array}$ \\
\hline T3 & $\mathrm{C}$ and $\mathrm{R}$ & RH & $\begin{array}{l}\text { few, irregular } \\
\text { uneven distribution }\end{array}$ & $\begin{array}{l}\text { complete and incomplete layers } \\
\text { thinner than in A types }\end{array}$ \\
\hline T4 & $\mathrm{C}$ and $\mathrm{R}$ & RH & $\begin{array}{l}\text { few, irregular } \\
\text { (as T3) }\end{array}$ & $\begin{array}{l}\text { complete and incomplete layers } \\
\text { (as T3) }\end{array}$ \\
\hline $\mathrm{T} 10$ & $\mathrm{C}$ and $\mathrm{R}$ & $\mathrm{S}$ & $\begin{array}{l}\text { few, irregular } \\
\text { (as T3) }\end{array}$ & $\begin{array}{l}\text { complete and incomplete layers } \\
\text { (as V965B) }\end{array}$ \\
\hline T15 & $\mathrm{C}$ and $\mathrm{R}$ & RH & more than with $\mathrm{T} 3$ & $\begin{array}{l}\text { complete and incomplete layers } \\
\text { (as T3) }\end{array}$ \\
\hline
\end{tabular}

$\mathrm{R}=$ rods; $\mathrm{C}=$ cocci; $\mathrm{ND}=$ not done, as a result of technical mishap; $\mathrm{S}=$ smooth; $\mathrm{RH}=$ rough.

\section{RESULTS}

\section{Surface morphology of strains of $P$. haemolytica biotype $A$}

The principal morphological features are summarised in tables I and II.

Ruthenium red staining. Aggregates of material densely stained with ruthenium red were present on the surface of cells of strain FAl but not on cells of the other representative of serotype Al (V965B). These aggregates protruded from a layer stained with ruthenium red external to the cell membrane (fig. 1). Bacteria derived from either liquid or solid media had the same appearance but unstained cells had no extraneous material on or near their cell walls.

A ruthenium red-stained layer external to the cell membrane was present in serotypes A1 (strains FA1 and V965B), A7 and A9. No ruthenium red-stained layer or aggregates were seen in the preparation from serotype $A 2$ whereas in serotype A6 there were aggregations without the continuous layer. Preparations from serotype A9 had finger-like projections of ruthenium red-stained material radiating from the cell surface (fig. 2).

Polycationic ferritin labelling. With serotype A1 strain FA1, conglomerations of ferritin particles lying approximately $70 \mathrm{~nm}$ from the cell wall were observed around the periphery of a few bacteria (fig. 3); with serotypes A1 (strains FA1 and V965B), A2, A6 and A9 the ferritin lay adjacent to the bacteria and in some cases formed a continuous band attached to the cell surface (fig. 4). Cells of serotype A7 had more 

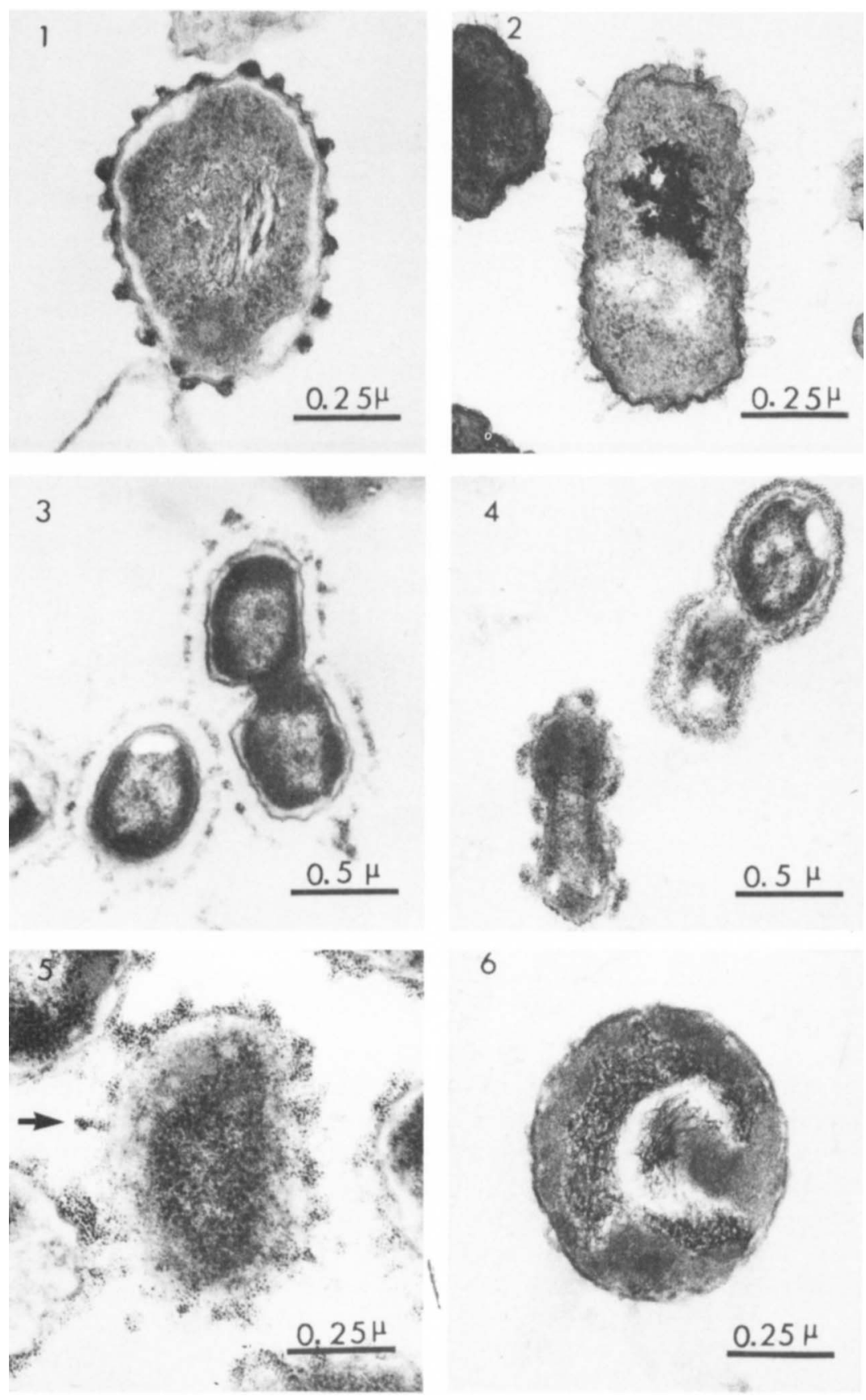

6

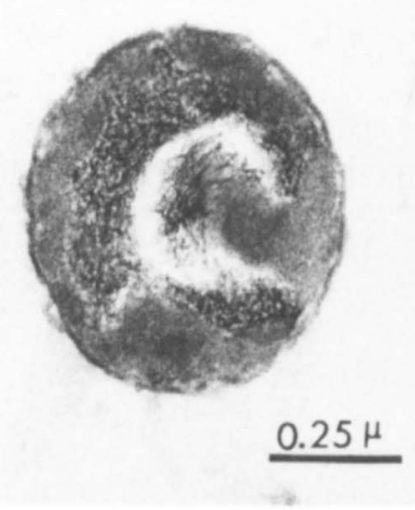

FIG. 1.-TEM of $P$. haemolytica serotype A1 strain FA1 stained with ruthenium red, showing aggregations of extracellular, densely-stained material on the cell surface. FIG. 2.-TEM of $P$. haemolytica serotype A9 with ruthenium red stained material projecting from the cell wall. FIG. 3.-TEM of polycationic ferritin-labelled $P$. haemolytica serotype A1 strain $\mathrm{FAl}$. The ferritin is present as a halo round the cells. FIG. 4.-TEM of polycationic ferritin-labelled $P$. haemolytica serotype A1 strain FA1. The ferritin is present as conglomerations adjacent to the cell walls and in some cases as a continuous band round the cells. FIG. 5. - TEM of polycationic ferritin-labelled $P$. haemolytica serotype A9. Note column (arrow) of cationic ferritin protruding from the organism. FIG. 6.--TEM of a polycationic ferritin-labelled preparation of a sodium salicylate-extracted cell of $P$. haemolytica serotype A1 strain FA1. Note the absence of ferritin as shown in figs. 3 and 4. 
discrete conglomerations attached to their walls and columns of ferritin were seen with serotype A9 (fig. 5).

Sodium salicylate-extracted cells. In extracted cells of serotype A1 (strain FA1) there was no evidence of material stained with ruthenium red or labelled with ferritin (fig. 6).

Scanning electronmicroscopy. P. haemolytica serotype A1 strains FA1 and V965B were uniformly cocco-bacillary when examined by SEM (fig. 7). Two surface structures were apparent. In some parts of each culture every cell surface was covered irregularly with many protrusions or blebs. These were approximately $90 \mathrm{~nm}$ in diameter and did not appear to be pedunculated. Strands of material were seen bridging the gaps between adjacent cells. Elsewhere the cells had markedly fewer surface protrusions. Incubation for 6 or $18 \mathrm{~h}$ did not appear to affect cell morphology.

The results of the examination of serotypes A1 (strain V965B), A6 and A9 are summarised in table II.

The test strain of serotype A2 was different from the other strains in biotype A; its surface was rough and the protrusions were fewer and more irregular in size (figs. 8 and 9).

\section{Surface morphology of strains of $P$. haemolytica biotype $T$}

Ruthenium red staining. With $P$. haemolytica biotype $\mathrm{T}$ strains the ruthenium red-stained material was arranged differently from that seen in the corresponding preparations from biotype $\mathrm{A}$. The aggregations of ruthenium red were smaller, and were closely associated with the cell membranes (fig. 10). With serotype T3 there were larger aggregations and a densely stained layer closely associated with the cell wall, similar to those seen with serotype A1. Thin strands of ruthenium red-stained material projected from the surface of serotypes T10 and T15. No material stained with ruthenium red was seen in the serotype $\mathrm{T} 4$ preparations.

Polycationic ferritin labelling. The conglomerations of polycationic ferritin formed thinner layers than those seen with the biotype A strains and were in close apposition to the cells. There was no evidence of a clear zone between the ferritin and the outer membrane of the cells (fig. 11). With serotype T10 the ferritin was dispersed more similarly to that seen with biotype A strains.

Scanning electronmicroscopy. P. haemolytica biotype T strains were pleomorphic in the cultures examined, and occurred in both coccal and cocco-bacillary forms (fig. 12). Strains of serotypes T3, T4 and T10 had fewer surface protrusions than the serotype A1 cells but serotype T15 had many such protrusions like serotype A1. The cell surface of the serotype T10 strain in the main experiment was smoother than that seen with the same strain in the preliminary experiment and with the other biotype $T$ strains. Serotypes T3 and T15 had short strands of material bridging adjoining cells (fig. 13). Longer strands lying across the surfaces of many of the cells were seen in the other $T$ serotypes (fig. 14).

\section{Light microscopy}

The capsules of $P$. haemolytica serotype A1 were seen as unstained, generally oval halos round the bacteria. These halos measured approximately $2 \mu \mathrm{m}$ at their greatest 

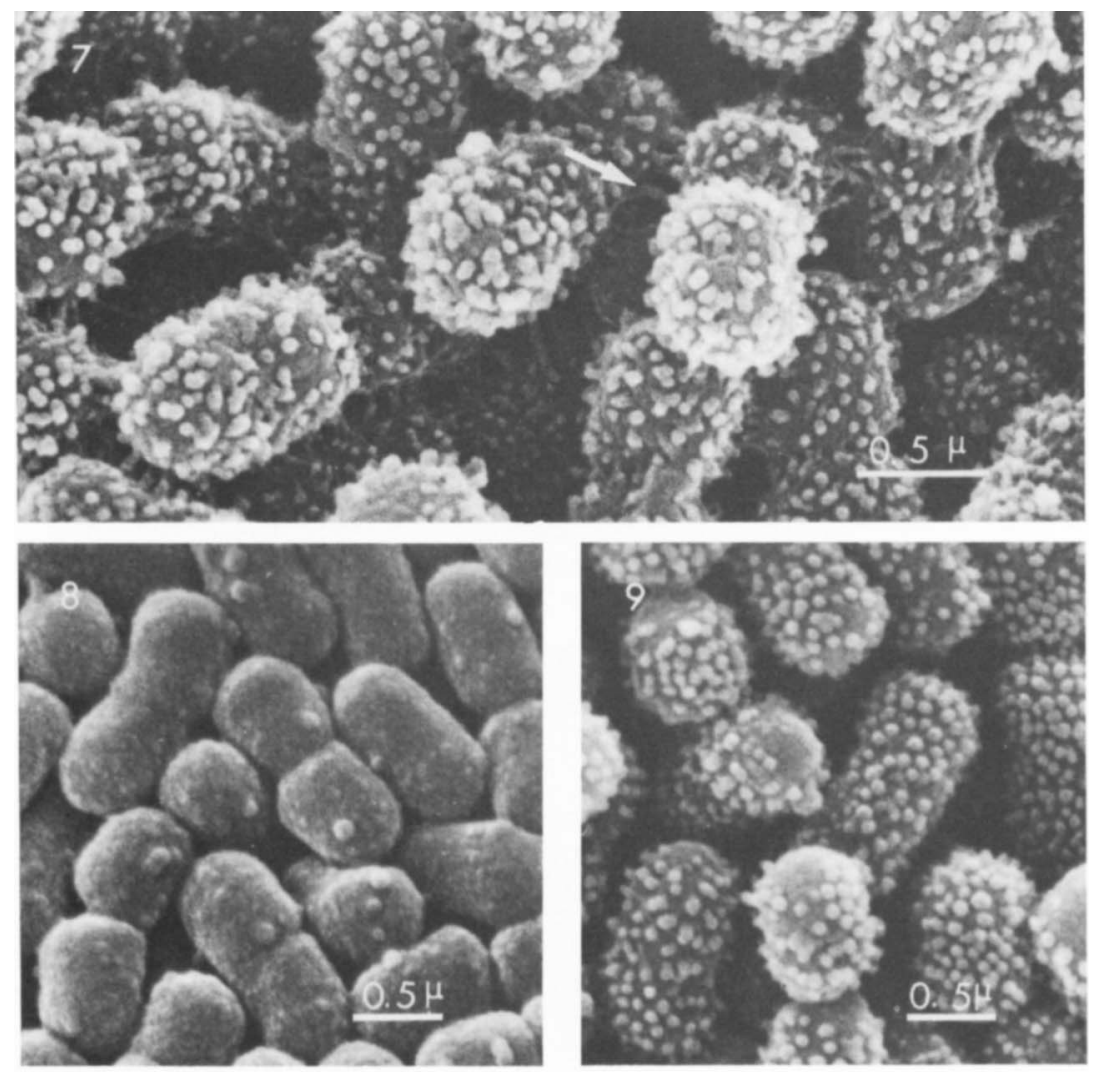

10
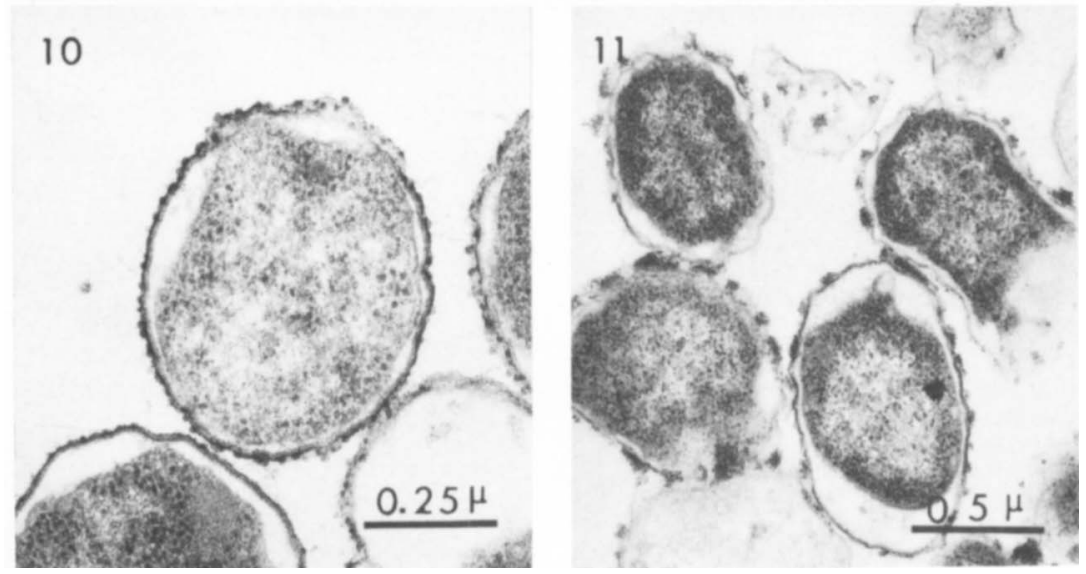

FIG. 7.-SEM of $P$. haemolytica serotype A1 strain FA1 showing numerous protrusions on the cell walls and strands (arrowed) between the cells. FIGS. 8 and 9.-SEM of $P$. haemolytica serotypes A2 and A9, respectively. A rough surface with few protrusions was seen on $P$. haemolytica serotype A2. $P$. haemolytica serotype A9 shows the same surface morphology demonstrated on $P$. haemolytica serotype A1. FIG. 10.-TEM of $P$. haemolytica serotype T10 stained with ruthenium red. FIG. 11.-TEM of polycationic ferritin-labelled $P$. haemolytica serotype T10. Ferritin is present adjacent to the cells. 

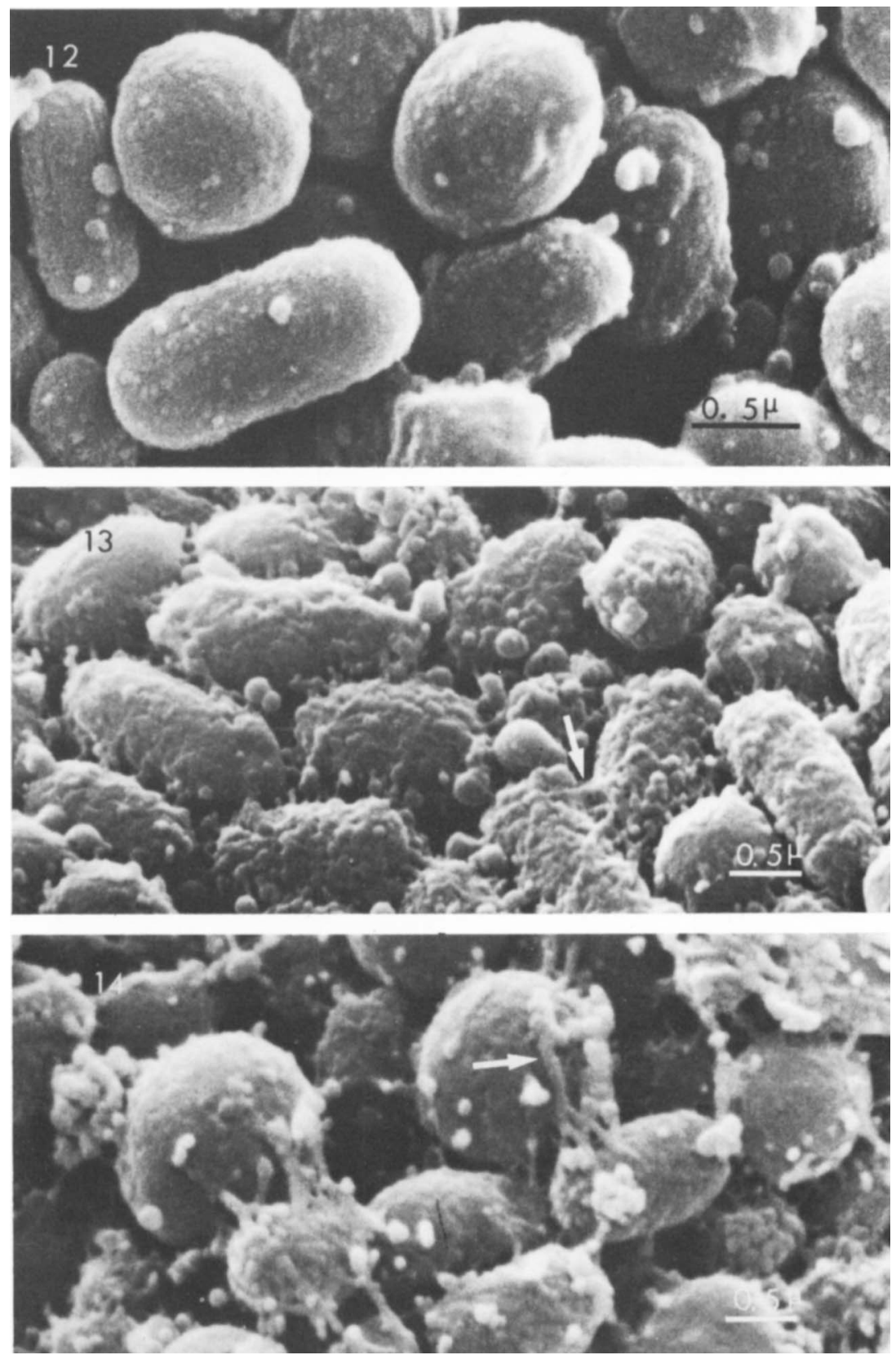

FIG. 12.-SEM of $P$. haemolytica serotype T10. There are few surface protrusions. FIG. 13.-SEM of $P$. haemolytica serotype $\mathrm{T} 3$ shows rough-surfaced bacteria with bridging material between adjoining cells (arrowed). FIG. 14. - SEM of $P$. haemolytica serotype T4. Material bridging these cells was less frequent than in P. haemolytica serotype T3 and longer strands, covering large areas were seen on the surface of these bacteria (arrowed). 
width along the long axis of the bacteria. Strain T10 had halos which followed the outline of the bacterial cell walls more closely and did not exceed $0.8 \mu \mathrm{m}$ in width.

\section{DisCUSSION}

Electronmicroscopic examination of the cell walls of $P$. haemolytica indicated that biotype A possessed a capsule. In the preliminary experiment, SEM of $P$. haemolytica serotype Al showed that the surface of many cells was covered with irregularly arranged protrusions. The disposition of the ruthenium red-stained polysaccharide material corresponded with the SEM distribution of protrusions, suggesting that the protrusions contained capsular polysaccharide material. Furthermore, an irregular halo was seen around some cells after labelling with polycationic ferritin, suggesting that the capsule sometimes formed an incomplete layer.

Our ultrastructural studies have confirmed and extended the work of Corstvet $e t$ al. (1982) who demonstrated the capsule of $P$. haemolytica serotype Al by conventional staining methods. Those authors concluded that after incubation for $22 \mathrm{~h}$ the capsule was disintegrating, probably due to enzymes secreted from the cells. The cultural conditions in Corstvet's studies were different from ours, so comparisons are difficult but there was no evidence of degradation of capsule when preparations made after incubation for 6 and $18 \mathrm{~h}$ were compared by SEM.

There were some anomalous findings with the A serotypes. Serotype A1 strain FA1 was used in the preliminary work. However we substituted strain V965B in the main experiment because strain FA1 subsequently gave anomalous results in mouse pathogenicity tests and we thought it advisable to use another strain (V965B) which, it transpired, did not have aggregations of ruthenium red-stained material, although a layer of ruthenium red-stained material was present. The SEM appearance of serotype A2 (fig. 8) was unlike that of the other A serotypes, e.g., A9 (fig. 9), in that there were very few surface protrusions and no ruthenium red-stained material was seen by TEM. However we do not know whether these findings would be true for all serotype A2 isolates in all conditions and what part technical variations play in determining morphology. For instance we have seen ruthenium red-stained material present as an even layer round the cells in an A2 strain examined directly from ovine pleural fluid and from broth. The aim of the present study was to examine representative serotypes of each biotype processed in identical conditions. The reproducibility of our findings requires further studies. Nevertheless serotype $\mathrm{A} 2$ differs in a number of respects from other biotype A strains, e.g., in immunogenicity in rabbits, mice and sheep (unpublished observations), and its unusual morphology and staining characteristics were not too surprising.

Finger-like projections of ruthenium red-stained material were seen on the serotype A9 strain (fig. 2) but not in any of the other biotype A or T strains. It is uncertain whether these are true morphological features or artefacts, but the fact that polycationic ferritin was similarly dispersed (fig. 5) suggests the former.

Immunological and chemical methods show at least two major antigens in the sodium salicylate-extract of $P$. haemolytica serotype A1 (Donachie et al., 1984). These have been identified as polysaccharide and one could be capsular in origin (Donachie, unpublished observations). Treatment of the cells with sodium salicylate, a method which has been used to remove the external antigens of $P$. haemolytica in the 
preparation of vaccines, removes the anionic sites on the surfaces of the cells to which polycationic ferritin and ruthenium red bind. This correlates with the finding of Donachie, Burrells and Dawson (1983) that treatment with sodium salicylate removed the surface antigens from $P$. haemolytica serotype A1 cells almost completely. We conclude, therefore, that the capsule of biotype A may occur in more than one form-as aggregations on or near the cell walls and as a discrete continuous envelope. These forms could reflect the different stages of growth of the bacterial cells within the cultures. Analogous studies have been performed on other gram-negative capsulated bacteria. Weiss et al. (1979) reported that polycationic ferritin attached to and penetrated a discrete continuous layer around the cells of Klebsiella spp. although, with the capsule swelling technique, the ferritin was seen as a continuous halo $250 \mathrm{~nm}$ from the cells. The appearance of a halo was similar to one of our findings except that the ferritin was more irregularly dispersed. Ruthenium red staining of $K$. pneumoniae has shown that the appearance of the capsule may depend largely on the method of preparation of the specimens for electronmicroscopy. Springer and Roth (1973) showed that the capsule of this organism was composed mainly of fibrils and spikes depending on the plane of section. We have seen an almost identical picture with some strains of $P$. haemolytica biotype A (unpublished observations). On the other hand, Woolcock and Mutimer (1978) noted a globular arrangement of ruthenium red material in $K$. pneumoniae and observed that different arrangements of capsular polymers was of limited significance because the capsule was mostly water and distortion must have occurred.

With three different methods--SEM, ruthenium red and ferritin labelling-our consistent finding of capsular aggregates in strains of $P$. haemolytica biotype A indicates that these strains are well endowed with capsular material. This may be important for the bacterium in two contexts. It may allow bacteria to remain unphagocytosed on the nasal mucosa and to resist antibacterial mechanisms in the lung alveoli. Kasper (1976) suggested that the capsule of Bacteroides fragilis may assist the virulence of this organism by interference with phagocytosis and the complementantibody system.

The staining reactions of $P$. haemolytica biotype $\mathrm{T}$ strains differed from those of serotype A1. By SEM, biotype T cells were more pleomorphic in shape and had fewer surface projections than those of serotype A1. The arrangement of ruthenium red-stained material indicated that the capsule was less well defined and this was also true of the ferritin labelled preparations. There did appear to be capsular material when Maneval's stain was used but the capsules of biotype T strains were thinner than those of biotype A strains.

Minor anomalies between strains in the T biotype were found. By SEM, serotype T10 had a smoother cell surface than did serotypes T3, T4 or T15 (fig. 14) and there were variations between serotype T15 and other $\mathrm{T}$ serotypes in the disposition of extracellular strands of material bridging and overlying cells. These findings and the variation in the ruthenium red- and polycationic ferritin-labelled preparations are of unknown significance, as is the presence of the two types of bridging strands.

The differences in morphology of biotype $\mathrm{T}$ strains from those of biotype $\mathrm{A}$, the difference in protein patterns of the biotypes on polyacrylamide gel electrophoresis (Thompson and Mould, 1975) and the low degree of DNA homology between strains of biotypes $\mathrm{A}$ and $\mathrm{T}$ (Biberstein and Francis, 1968) all serve to reinforce Smith and 
Thal's (1965) assertion that $P$. haemolytica biotype T does not belong to the species $P$. haemolytica. There are also epidemiological differences in the diseases produced by each organism and in the pathogenesis of the diseases (Gilmour, 1980). We believe that further study of the morphological differences within and between the biotypes is necessary and may clarify the taxonomy of $P$. haemolytica.

The authors thank Mr E. W. Gray for comments and advice on the electronmicroscopy.

\section{REFERENCES}

Biberstein E L, Gills M, Knight H D 1960 Serological types of Pasteurella haemolytica. Cornell Veterinarian 50:238-300.

Biberstein E L, Francis C K 1968 Nucleic acid homologies between the A and T types of Pasteurella haemolytica. Journal of Medical Microbiology 1:105-108.

Corstvet R E, Gentry M J, Newman P R, Rummage J A, Confer A W 1982 Demonstration of age-dependent capsular material on Pasteurella haemolytica serotype 1. Journal of Clinical Microbiology 16:1123-1126.

Donachie W, Burrells C, Dawson A 1983 Specificity of the enzyme-linked immunosorbent assay (ELISA) for antibodies in the sera of specific pathogen-free lambs vaccinated with Pasteurella haemolytica antigens. Veterinary Microbiology 8:199-205.

Donachie W, Gilmour N J L, Mould D L, Poxton I R 1984 Comparison of cell surface antigen extracts from two serotypes of Pasteurella haemolytica. Journal of General Microbiology 130:1209-1216.

Gilmour N J L 1980 Pasteurella haemolytica infections in sheep. Veterinary Quarterly 2:191-197.

Gilmour N J L, Martin W B, Sharp J M, Thompson D A, Wells P W, Donachie W 1983 Experimental immunisation of lambs against pneumonic pasteurellosis. Research in Veterinary Science 35:80-86.

Howard C J, Gourlay R N 1974 An electron-microscopic examination of certain bovine mycoplasmas stained with ruthenium red and the demonstration of a capsule on Mycoplasma dispar. Journal of General Microbiology 83:393-398.

Kasper D L 1976 The polysaccharide capsule of Bacteroides fragilis subspecies fragilis: Immunochemical and morphologic definition. Journal of Infectious Diseases 133:79-87.

Maneval W E 1941 Staining bacteria and yeasts with acid dyes. Stain Technology 16:13-19.

Ryter A, Kellenberger E, Birch-Andersen A, Maaloe O 1958 Etude au microscope électronique de plasmas contenant de l'acide désoxyribonucléique. 1. Les nucléoides des bactéries en croissance active. Zeitschrift fur Naturforschung Section B 13:597-605.

Smith G R 1961 The characteristics of two types of Pasteurella haemolytica associated with different pathological conditions in sheep. Journal of Pathology and Bacteriology $81: 431-440$.

Smith J E 1974 Genus Pasteurella. In: Buchanan R E, Gibbons N E (eds) Bergey's Manual of determinative bacteriology, 8th edn. Williams and Wilkins Co., Baltimore p 370 .

Smith J E, Thal E 1965 A taxonomic study of the genus Pasteurella using a numerical technique. Acta Pathologica et Microbiologica Scandinavica 64:213-223.

Springer E L, Roth I L 1973 The ultrastructure of the capsules of Diplococcus pneumoniae and Klebsiella pneumoniae stained with ruthenium red. Journal of General Microbiology 74:21-31.

Thompson D A, Mould D L 1975 Protein electrophoretic pattern of Pasteurella haemolytica. Research in Veterinary Science 18:342-343.

Wagner B, Wagner M, Kubin V, Ryc M 1980 Immunoelectron microscopic study of the location of group-specific and protein type-specific antigens of group B streptococci. Journal of General Microbiology 118:95-105.

Weiss R, Schiefer H G, Krauss H 1979 Ultrastructural visualization of Klebsiella capsules by polycationic ferritin. FEMS Microbiology Letters 6:435-437.

Wessman G E 1966 Cultivation of Pasteurella haemolytica in a chemically defined medium. Applied Microbiology 14:597-602.

Woolcock J B, Mutimer M D 1978 The capsules of Corynebacterium equi and Streptococcus equi. Journal of General Microbiology 109:127-130. 